\title{
THE BARBADOS CLOUD OBSERVATORY Anchoring Investigations of Clouds and Circulation on the Edge of the ITCZ
}

\author{
by Bjorn Stevens, David Farrell, Lutz Hirsch, Friedhelm Jansen, Louise Nuijens, Ilya Serikov, \\ Björn Brügmann, Marvin Forde, Holger Linne, Katrin Lonitz, and Joseph M. Prospero
}
The Barbados Cloud Observatory advances understanding of clouds, circulation, and climate sensitivity through sustained observations on the edge of the ITCZ.

C louds are at the heart of some of the most fascinating questions posed by climate change. As highlighted by Bony et al. (2015), the coupling between clouds and circulation systems influences not just the pace of warming but also the pattern of the response to this warming. Cumulus clouds confined to the lower troposphere, like those that prevail in the trades, are well appreciated as being central to the question as to how much surface temperatures will rise with increasing concentrations of carbon dioxide in the atmosphere (Bony and Dufresne 2005; Boucher et al. 2013), but their influence on circulation systems is only beginning to be understood.
The surface evaporation engendered by clouds in the trades is important to the structure of tropical convergence zones (Tiedtke 1989; Neggers et al. 2007), and their radiative effects drive the tendency of deeper convection to aggregate (Emanuel et al. 2014; Muller and Bony 2015). Understanding climate change is thus synonymous with understanding patterns of cloudiness. Earth's atmosphere supports many different cloud regimes; nonetheless, advancing understanding of only those in the trade wind regions will advance the science on many fronts, but this requires data, of which there is a paucity in the trades. affiliations: Stevens, HiRsch, Jansen, Nuijens, Serikov, Brügmann, AND LINNE-Max-Planck-Institut für Meteorologie, Hamburg, Germany; FarReLl AND Forde-Caribbean Institute for Meteorology and Hydrology, Bridgetown, Barbados; LoNiTZ-European Centre for Medium-Range Weather Forecasts, Reading, United Kingdom; ProsPERO-Rosenstiel School of Marine and Atmospheric Science, University of Miami, Miami, Florida

CORRESPONDING AUTHOR: Bjorn Stevens, Max-Planck-Institut für Meteorologie, Bundesstrasse 53, 20146 Hamburg, Germany
E-mail: bjorn.stevens@mpimet.mpg.de

The abstract for this article can be found in this issue, following the table of contents. DOI:10.1175/BAMS-D-14-00247.I

A supplement to this article is available online (10.II75/BAMS-D-14-00247.2)

In final form 6 September 2015

(O2016 American Meteorological Society 
$\mathrm{BCO}$

ECHAM 6.2

ECHAM 6.3

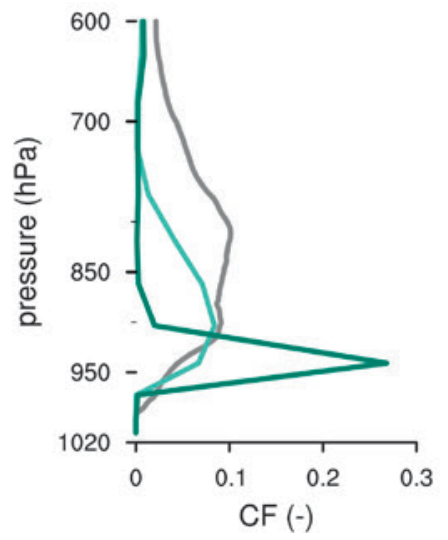

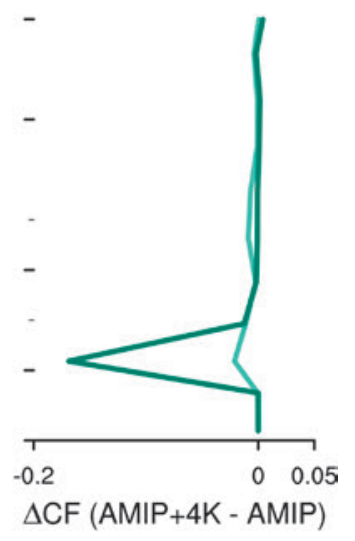

FIG. I. (left) Cloud fraction and (right) change in cloud fraction for the ECHAM6 atmospheric general circulation model. Shown by the teal-colored lines are two versions of the model that differ in the mixing parameter used in the parameterization of shallow convection. Cloud fraction derived from measurements (gray) at the Barbados Cloud Observatory is shown for reference in (left).

The way in which a poor understanding of low clouds translates into uncertainty in the response of the climate system to forcing can be illustrated by a simple example. Through the course of development of the new version of the Max Planck Institute Earth System Model (MPI-ESM), particular attention was devoted to fixing errors that had been identified in an earlier version of that model (Stevens et al. 2013). The initial result of this process was a model that had an abundance of low clouds, concentrated near the cloud base, in the trades, and over the oceans more generally. Because the cloudiness in this layer proved to be very sensitive to the surface temperature (Fig. 1), this version of the model has an exceptionally strong temperature response to radiative forcing. But cloudiness in this cloud-base layer also proved to be sensitive to parameter settings that control mixing by shallow cumulus. For a different choice of parameters, the cloud-base peak in cloud amount is much less pronounced, it changes less with warming, and the climate sensitivity of the model is more than halved (Fig. 1). This simple example is consistent with analyses of other models (Sherwood et al. 2014; Brient et al. 2016) and helps explain why a better understanding of trade wind clouds is at the center of efforts to better understand the expected pace of warming.

The importance of trade wind convection makes it all the more surprising that measurements of cloud-controlling factors in the trades are rare. Major measurement initiatives are frequent in regions of stratocumulus (e.g., Stevens et al. 2003; Bretherton et al. 2004; Wood et al. 2011; Gerber et al. 2013; Russell et al. 2013) as are field programs in regions of deeper convection (e.g., Betts 1974; Johnson et al. 1999; Raymond et al. 2003; Chen et al. 2015). In both cases, regimes of more broken, trade wind-like clouds may be sampled serendipitously but are not generally the focus of measurements. In the few cases of trade wind studies, the focus has been more on rain forming processes than on the factors controlling cloudiness and convection (Rauber et al. 2007; Knight and Miller 1998; Smith et al. 2009; Siebert et al. 2013). The last field studies designed to understand larger-scale cloud-controlling factors in the trades, the Barbados Oceanographic and Meteorological Experiment (BOMEX; Holland 1970) and the Atlantic Trade Wind Experiment (ATEX; Augstein et al. 1974), were nearly 50 years ago. These seminal studies, both of which took place in 1969, still constitute the benchmark for simulations of cloudiness in the trades (Stevens et al. 2001; Siebesma et al. 2003).

An absence of in situ measurements has only been tolerable because of a growing record of satellite measurements (e.g., Stephens et al. 2008; Loeb et al. 2009; Winker et al. 2010; Chepfer et al. 2010). Although helpful, satellites have several disadvantages: trade wind clouds comprise many clouds whose diminutive size is poorly sampled by satellites; the presence of upper-level clouds, whether it be overlying cirrus or stratocumulus cumulogenitus near the trade inversion, obscures a view of processes near cloud base; the highest-resolution sensors poorly sample evolution in time; and, finally, the use of satellite measurements to advance process understanding is often dependent on meteorological reanalyses, which in the lower tropical troposphere are not as well constrained by data as at midlatitudes.

To fill this gap in the empiricism and thereby advance understanding of the trade winds and their clouds, we have established a cloud observatory on the island of Barbados $\left(13^{\circ} \mathrm{N}, 59^{\circ} \mathrm{W}\right)$. Our observatory, the Barbados Cloud Observatory (BCO), was constructed very much in the spirit of long-term, European, ground-based observatories that form the basis of Cloudnet (Illingworth et al. 2007) and the U.S. Department of Energy's [Atmospheric Radiation Measurement (ARM)] climate research facilities (Moran et al. 1998; Clothiaux et al. 2000; Ackerman and Stokes 2003; Long et al. 2013). These other observatories are all situated in the extratropics, so that the BCO stands out as the only 

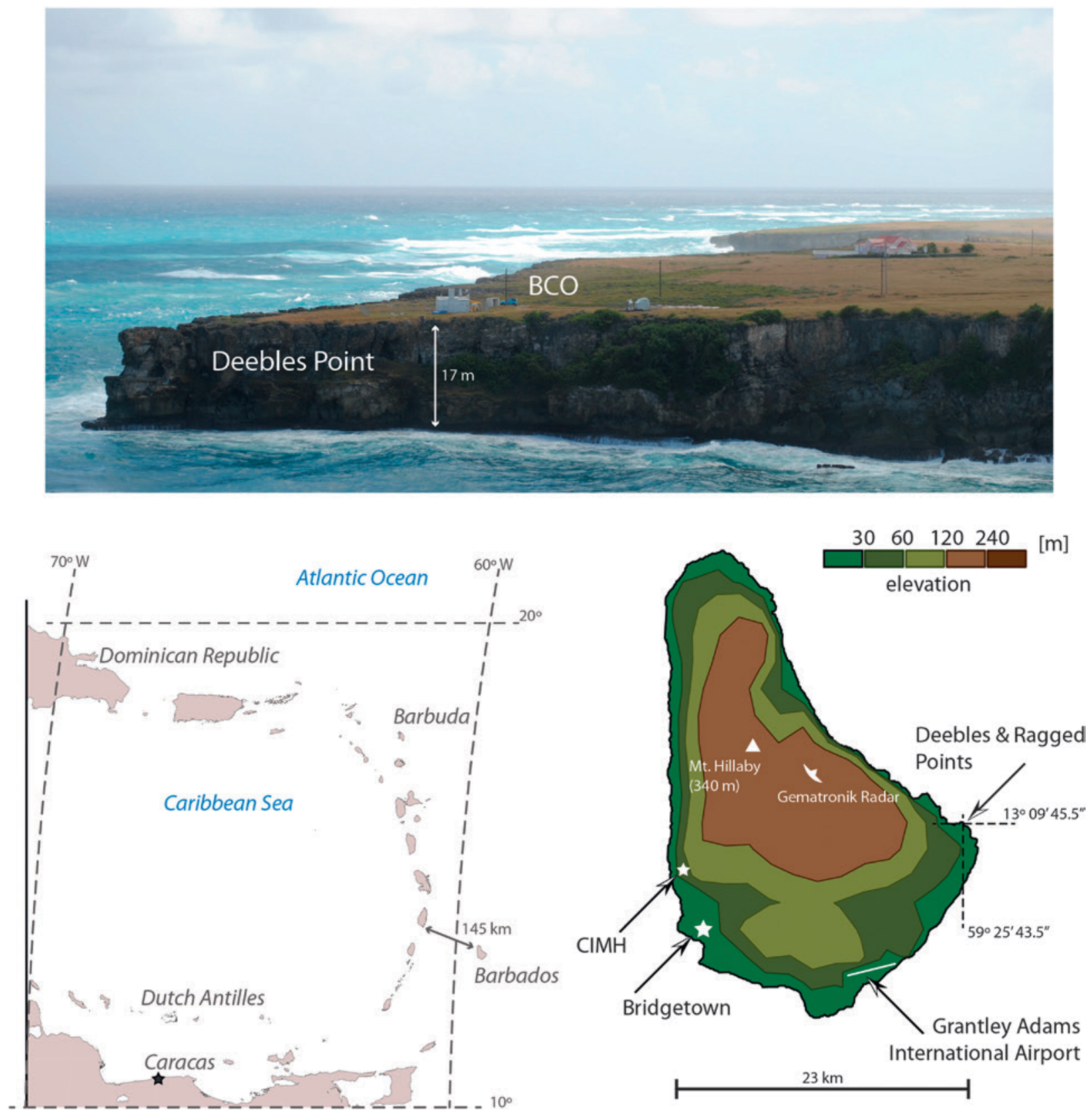

FIG. 2. Setting of BCO: (top) photograph of the observatory as seen from neighboring Ragged Point; (bottom left) location of Barbados relative to other landmasses that give definition to the Caribbean Sea; and (bottom right) observational infrastructure on Barbados and island relief as taken from the I-min gridded elevations/bathymetry for the world (ETOPOI) global relief model (Amante and Eakins 2009).

advanced, long-term, ground-based measurement station in the broader maritime tropics. As such, in addition to informing understanding of factors controlling clouds in the tropics in its own right, the BCO is increasingly being used as an anchor for field studies more broadly.

In the following pages, we explain why we chose Barbados as the location for our observatory, the general meteorological conditions at the observatory, and the evolving measurement infrastructure at the BCO. A few of the insights that have been gleaned from the first 5 years of operations are also presented. This information (more information can be found online at http://dx.doi.org//0.1 175/BAMSD-14-00247.2) is provided to help orient those interested in using our data (which is freely available to the broader community) or in collaborating on the design of future field studies anchored by the BCO. 

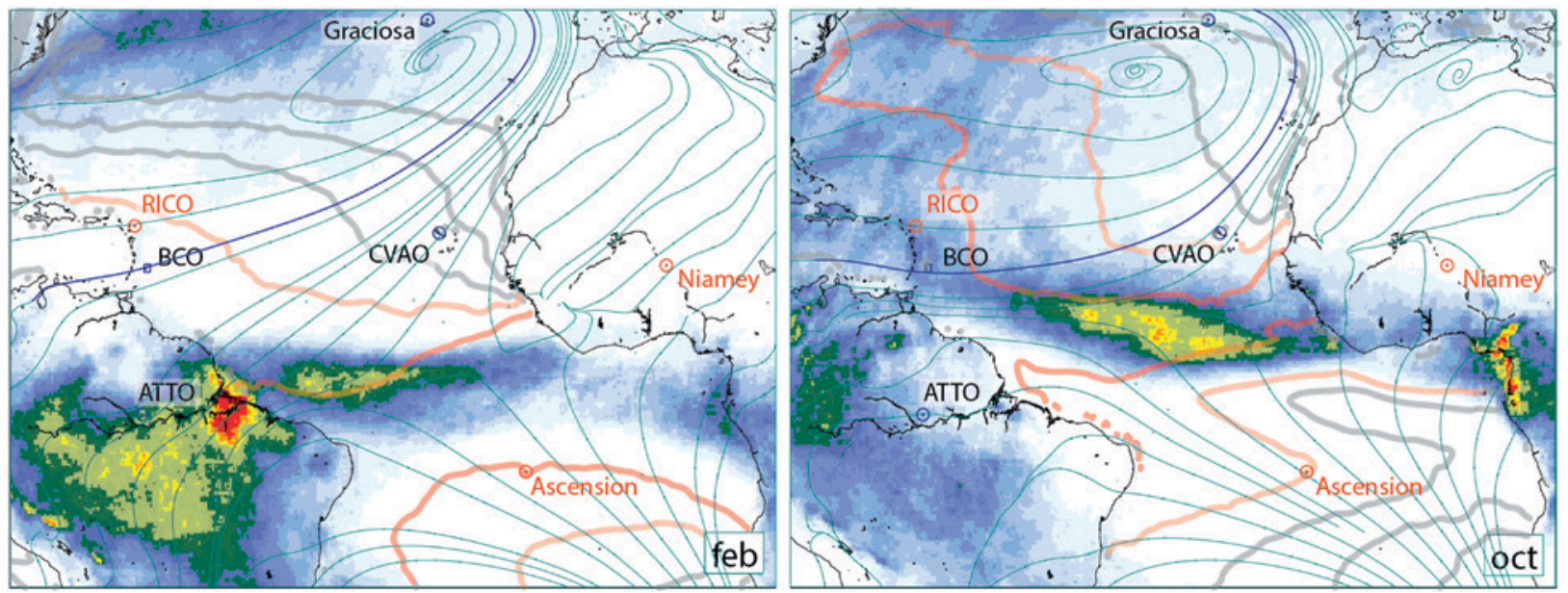

Fig. 3. Seasonal snapshots of tropical Atlantic and neighboring landmasses for climatologically (right) wettest (October) and (left) driest (February) months on Barbados. Shown are shaded contours of Tropical Rainfall Measuring Mission (TRMM) precipitation (ranging from I to $\left.16 \mathrm{~mm}^{\text {day }}{ }^{-1}\right)$, streamlines of near-surface ( $10 \mathrm{~m}$ ) winds from the Interim European Centre for Medium-Range Weather Forecasts (ECMWF) Reanalysis (ERA-Interim), and sea surface temperature monthly climatological mean (contour lines every $2^{\circ} \mathrm{C}$ with orange lines denoting $26^{\circ}$ and $28^{\circ} \mathrm{C}$ isotherms) from Advanced Microwave Scanning Radiometer for Earth Observing System (AMSR-E) measurements. Other BCO-like observatories are also indicated on the map; these include permanent stations such as the Amazon Tall Tower Observatory (ATTO), the Cape Verde Atmospheric Observatory (CVAO), and the ARM facility on Graciosa, as well as locations of recent field measurements as part of RICO that took place in 2004 and 2005 and the ARM Mobile Facility that was located in Niamey, Niger, through 2006 as part of the African Monsoon Multidisciplinary Analyses (AMMA) program. From June 2016 to May 2017, the ARM Mobile Facility will be deployed on Ascension Island.

WHY BARBADOS? In a few words: because it is relatively flat, remote, logistically attractive, and meteorologically well situated.

Barbados sits firmly in the Atlantic Ocean, some $150 \mathrm{~km}$ east of the Windward Islands that form the eastern border of the Caribbean Sea. In the windward direction, the Cape Verde Islands, nearly $3,700 \mathrm{~km}$ away, are the nearest land. Dakar, Senegal, on the westernmost point of the African mainland, is more than $4,500 \mathrm{~km}$ away. Unlike the Windward Islands, which are volcanic in origin and whose peaks (reaching nearly $1,500 \mathrm{~m}$ ) interact strongly with the impinging trades (Smith et al. 2009), Barbados was formed by gradual but episodic tectonic uplift associated with the collision of the Caribbean and Atlantic plates and is relatively flat (Fig. 2).

A well-maintained network of roads, and access to Internet and power across the island, greatly facilitates the maintenance of advanced remote sensing instrumentation, as does an international airport and deep-water harbor. The Cave Hill campus of the University of the West Indies and the Caribbean Institute for Meteorology and Hydrology (CIMH) are also located on Barbados. Together they provide access to students, technical expertise, and an understanding of the local meteorology. The CIMH supports the maintenance of a network of measurement stations, including a modern Gematronik S-band polarimetric radar that has been in operation since 2008 , and is presently celebrating 50 years of cooperation with the University of Miami in the establishment and maintenance of mineral dust measurements (e.g., Prospero and Lamb 2003).

Although Barbados is a relatively populous island, most of the development is on its southwestern (downwind) side. Of its roughly 300,000 inhabitants, $80 \%$ of the population is concentrated in the five parishes in and around the lowlands surrounding the capitol of Bridgetown. As a result the upwind side of the island, where the BCO is situated, remains relatively wild and undisturbed.

\section{METEOROLOGICAL CONDITIONS SAM- PLED BY THE OBSERVATORY. The seasonal} migration of the intertropical convergence zone (ITCZ) subjects Barbados to a wide variety of tropical circulation systems (Fig. 3), including the occasional hurricane; Tomas formed over the BCO in 2010. Subsidence prevails during the dry winter months from December to June, and low-level convergence supports convection in a wet season that peaks in October but lasts from June to December (Fig. 4). In 


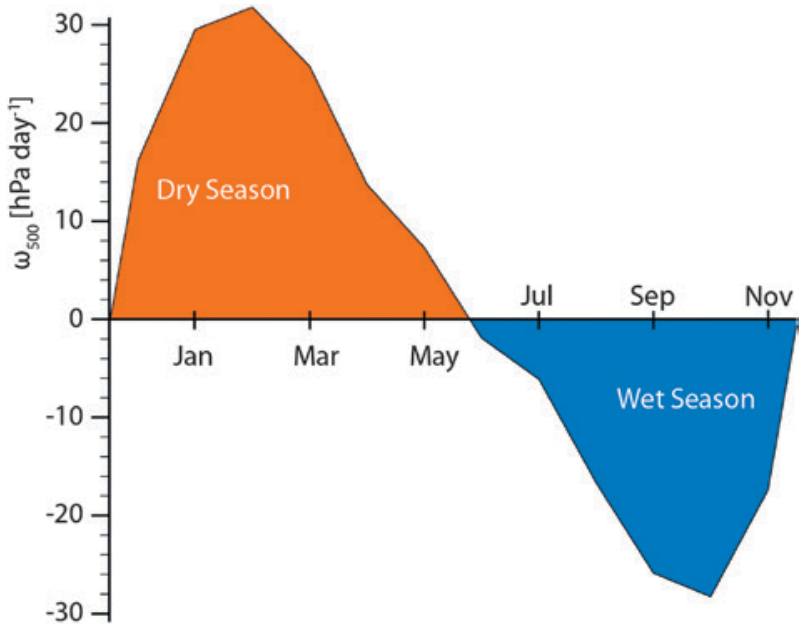

Fig. 4. Monthly climatology (seasonal cycle) of midtropospheric vertical pressure velocity $\omega_{500}$ over Barbados region $\left(12^{\circ}-15^{\circ} \mathrm{N}, 58^{\circ}-60^{\circ} \mathrm{W}\right)$ as represented in the ERA-Interim dataset (1989-2007).

the annual mean, the distribution of the vertical motion (at $500 \mathrm{hPa}$ ) mirrors that of the broader tropics (Fig. 5), so despite its pronounced seasonal cycle, the mean vertical motion nearly vanishes $(-2 \mathrm{hPa})$. In contrast, at Nauru (one of the former ARM sites) the annually averaged vertical velocity is nearly an order of magnitude larger $(-16 \mathrm{hPa})$. During the wet season, less precipitation forms over Barbados, as compared to other regions in the tropics with the same amount of vertical motion (white dots, Fig. 5). This is indicative of greater ventilation by the low-entropy air of the subtropics-even when deep convection prevails, Barbados still feels the influence of the trades.

Seasonal shifts in the wind also modulate aerosol transport, including that from biomass burning, and mineral dust raised from Africa (e.g., Fig. 6), helping to create a laboratory for understanding aerosolcloud and aerosol-radiation interactions. An analysis of 2 years of daily 10-day back trajectories, initiated over Barbados at a height of $3 \mathrm{~km}$ above sea level, indicates that in the dry season (December-May) roughly half of the air masses originate east of $55^{\circ} \mathrm{W}$ and north of $10^{\circ} \mathrm{N}$. This fraction increases to nearly two-thirds in the wet season (June-November). Of these back trajectories, most (55\%) pass over the European or African continents during the wet season but relatively few (8\%) do so during the dry season. In both seasons streamlines of the low-level $(10 \mathrm{~m})$ flow connect Barbados to a second measurement station on Graciosa (part of the Azores), well upstream of Barbados (cf. Fig. 3); during the wet season the BCO also samples cross-equatorial flow that may have passed over Ascension Island $\left(8^{\circ} \mathrm{S}, 14^{\circ} \mathrm{W}\right)$, where the
ARM Mobile Facility will be operating between June 2016 and May 2017. The Graciosa station (operated temporarily during 2009 and 2010; Rémillard et al. 2012; Wood et al. 2015) began operations as a permanent station in September of 2013.

The transport of mineral dust to Barbados maximizes in June and July (Doherty et al. 2008; Prospero and Lamb 2003). During this time the Saharan Air Layer is frequently observed above the trade inversion in the layer of easterlies between 1.5 and $4.0 \mathrm{~km}$ (Prospero and Carlson 1972; e.g., Fig. 6). The peak in the dust layer above the trade inversion likely reflects the efficiency of wet scavenging and the removal of dust below the inversion, where shallow cumulus are prevalent and frequently precipitate. Dust transport from Africa has long motivated measurements on Barbados (Prospero 1968). Its prevalence was noted in early field studies such as BOMEX (Holland and Rasmusson 1973), and motivated a program of continuous dust and aerosol measurements that continue to this day (Prospero and Lamb 2003). Studies have shown that it takes about a week for the dust to be transported from its source regions in Africa and that the summertime dust transport is modulated by easterly waves, with tenfold or larger daily variations in the amount of dust. Aged dust is known to be effective as a cloud condensation nuclei (CCN). Hence,

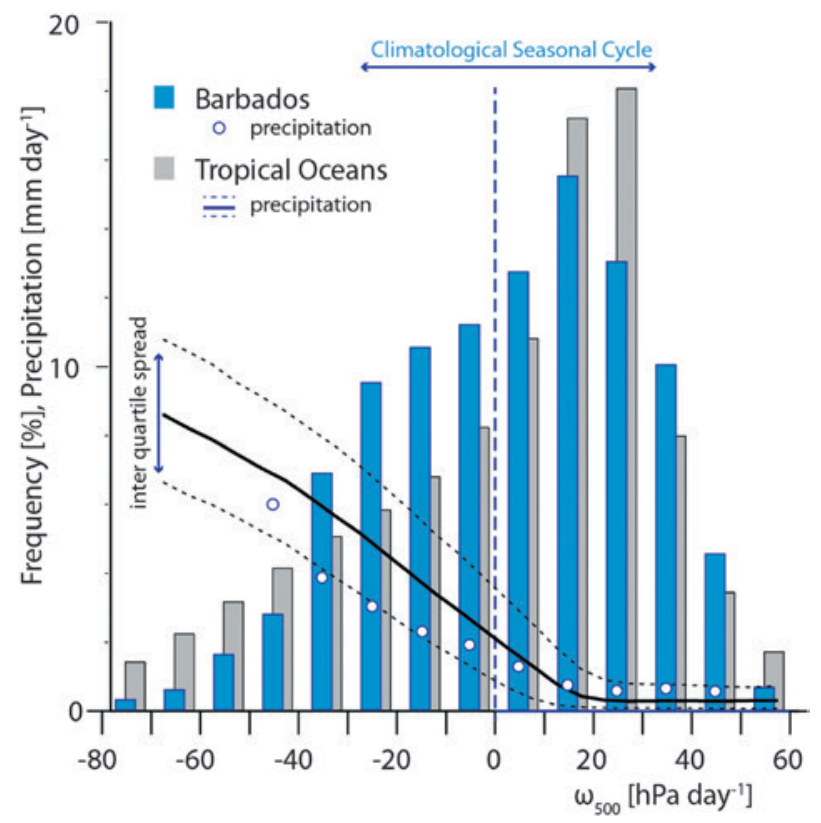

FIG. 5. Distribution of monthly averaged vertical pressure velocity from the ERA-Interim data overlaid with precipitation conditioned on a given range of vertical pressure velocity for the entire maritime tropics $\left(30^{\circ} \mathrm{S}-30^{\circ} \mathrm{N}\right)$ and over the Barbados region $\left(12^{\circ}-15^{\circ} \mathrm{N}, 58^{\circ}-60^{\circ} \mathrm{W}\right)$ as represented in the ERA-Interim dataset (1989-2007). 

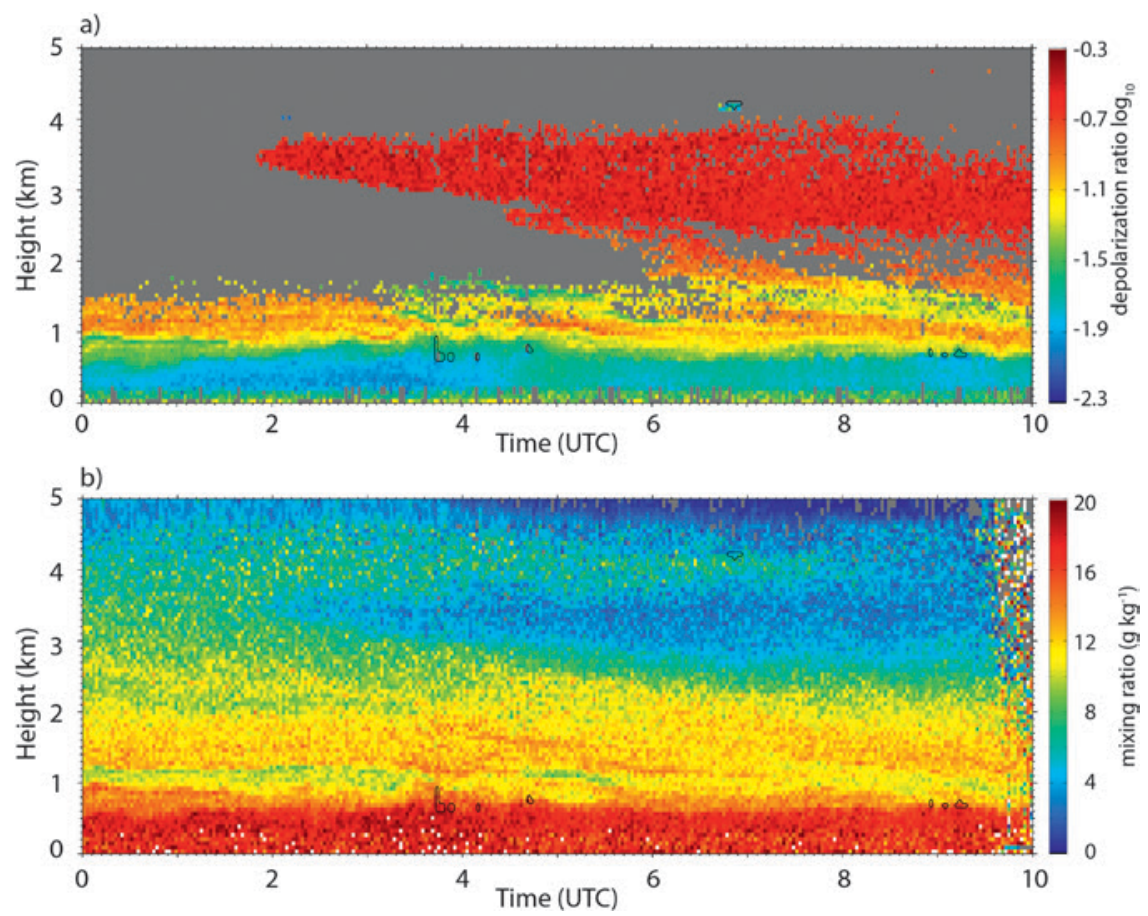

FIG. 6. Time series of Raman lidar profiles showing a dust intrusion over the BCO on 10 Aug 20II. (a) The Saharan Air Layer is well visualized by a strong increase in the linear depolarization in a layer near $3 \mathrm{~km}$ after 0200 UTC. (b) The humidity retrievals from the Raman lidar show the Saharan Air Layer is also very dry.

the sedimentation of dust and its downward mixing through entrainment provide a source of $\mathrm{CCN}$ to the boundary layer (Twohy et al. 2009). The area near and upstream of Barbados thus provides a natural laboratory for exploring the sensitivity of shallow cumulus to large changes in the number of available CCN (Siebert et al. 2013).

THE BARBADOS CLOUD OBSERVATORY. The $\mathrm{BCO}$ is situated at Deebles Point, a relatively remote promontory on the upwind (eastern) shore of the island (Fig. 2). The instruments are set back from the shore by about $30 \mathrm{~m}$, and the $17-\mathrm{m}$ elevation of the site keeps it above the wave break. Ragged Point, which lays across a small cove $400 \mathrm{~m}$ to the northwest, is the site of aerosol measurements by the University of Miami group, an Aerosol Robotic Network (AERONET) station (operating since 2007), and one of only two Advanced Global Atmospheric Gases Experiment (AGAGE) stations in the tropics (operating since 1978; Prinn et al. 2000).

The measurements at the $\mathrm{BCO}$ are centered around active radar and lidar profiling of precipitation, clouds, water vapor, and aerosol. An overview of the $\mathrm{BCO}$ instrumentation is provided in Table 1 (technical and operational details are in the electronic supplement). The lidar and cloud radar are among the most advanced instruments of their kind worldwide and have formed the core for a broader and larger suite of instruments that have been in operation intermittently or have only come online more recently. These include a second scanning cloud radar, a water vapor differential absorption lidar (DIAL), and a microwave radiometer for atmospheric profiling (Löhnert et al. 2004). Beginning in March 2015, instrumentation has been added for measuring broadband visible and infrared irradiances for eventual inclusion in the Baseline Surface Radiation Network. The scanning cloud radar has been augmented (and will eventually

be replaced) by a newer system that has a much larger $(2 \mathrm{~m})$ dish, greater sensitivity, and is set inside a clutter fence to remove signals from sidelobes. A wind lidar has also been installed and profiles the wind through the lower $2 \mathrm{~km}$ of the atmosphere. A new high-power Raman lidar system is under development and will be installed at the BCO in early 2017. The new lidar system will have the ability to measure daytime water vapor, and its high power will facilitate much higherfrequency humidity profiling. Its measurements, on the scale of meters, will thus resolve the humidity structure at the very edge of a cloud and help inform understanding of cloud mixing processes.

\section{WATER VAPOR, AEROSOLS, CLOUDS, AND PRECIPITATION AT THE BCO. An} ability to anticipate changes in climate depends on the extent to which insight into processes relevant for climate change can be inferred from present and past fluctuations of the climate system. Below we give a glimpse of some of what has been learned over the first 5 years of measurements, also to guide the anticipated use of our data by others.

The seasonal migration of the ITCZ and the accompanying circulation shifts are associated with large changes in cloudiness. This is evident when 

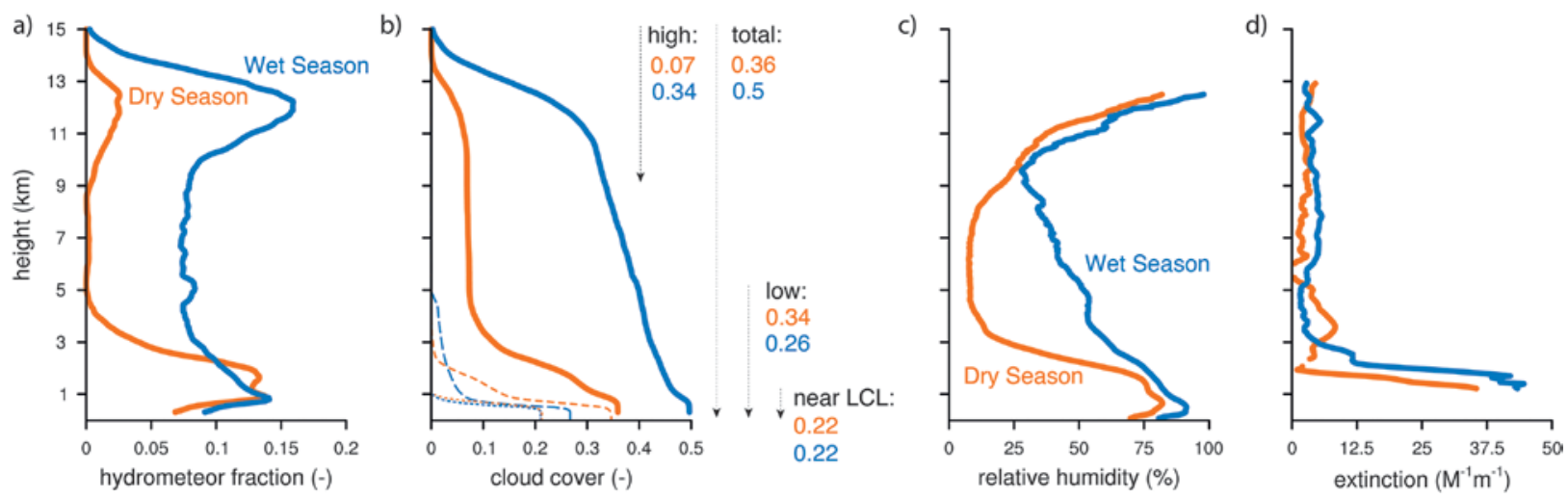

Fig. 7. Vertical profile of (a) hydrometeor fraction from radar, (b) cumulative (upward) cloud cover from radar (thick solid) [ceilometer up to $5 \mathrm{~km}$ (thin dashed) and up to I km (thin dotted)], (c) relative humidity, and (d) clear-sky (aerosol) extinction. Data in (c) and (d) are from the Raman lidar. Shown are results from Oct (wet season) and Feb (dry season).

comparing measurements in February and October as compiled during the first two years of operations at the BCO. During October (taken to be representative of the wet season) midlevel and high cloudiness (above $3 \mathrm{~km}$ ) is pronounced. The contribution of high clouds (above $9 \mathrm{~km}$; e.g., Fig. 7a) to the cumulative ceilometer cloud fraction is nearly 5 times larger during October than it is in February (Fig. 7b). Because cloudiness in the lower troposphere changes much less across the seasons, cloud cover is greatest overall during the wet season; radar-derived cloud cover is 0.5 , compared to 0.36 during the dry season (blue vs orange lines in Fig. $7 \mathrm{~b}$ ).

What is surprising, and what could not have been readily deduced from satellites, is that the contribution of clouds below $1 \mathrm{~km}$ to cloud cover has little seasonality. Integrating upward from the surface, cloud cover from low clouds in February is indistinguishable $(0.22$; dotted lines below $1 \mathrm{~km})$ from that which is measured in October or any other month for that matter. This finding has obvious implications for the questions raised by Fig. 1. Differences in the downward accumulated cloud cover begin to become evident when including cloudy points that first occur between 1 and $5 \mathrm{~km}$ (dashed line). Cloud cover increases only slightly to 0.26 in the wet season and substantially to 0.34 in the dry season when contributions in this layer are considered. Although the wet season has more high cloud that contributes to cloud cover, in the dry season this is offset by the additional cloud between 1 and $5 \mathrm{~km}$. A secondary peak in cloudiness in the layer between 1.5 and $3 \mathrm{~km}$ is due to stratocumulus cumulogenitus: that is, stratiform clouds formed by the detrainment of condensate from cumulus convection (Nuijens et al., 2014). On monthly time scales low-cloud amount correlates most strongly with wind speed, which is higher in the dry season. On the basis of reanalysis and satellite retrievals evaluated using data from the BCO, Brueck et al. (2015) show that enhanced stability in the lower troposphere during the dry season also appears to play a role in the enhanced low-level cloudiness.

The vertical distribution of cloud fraction is predominantly bimodal over Barbados (Fig. 7), although the hint of a tertiary maximum in cloudiness at $6.5 \mathrm{~km}$ is evident during the dry season. Even if significant, this third maximum appears somewhat higher than the average melting-level cloudiness highlighted by Johnson et al. (1999). Analysis of the radar data show this peak in cloudiness to be associated with detrainment from isolated cumulus congestus systems. No such feature is evident in the wet season, although midlevel cloudiness is on average higher as compared to the dry season, and the atmosphere is more humid through a deeper layer. During February the mean humidity between 4 and $9 \mathrm{~km}$ is near $10 \%$; in the wet season it is closer to $50 \%$. Differences between the wet and dry season humidity are strikingly similar to differences between the dry and precipitating regions in simulations of radiative convective equilibrium (e.g., Fig. 4 in Bretherton et al. 2005), suggesting that these rather idealized simulations might capture some of the effects associated here with much larger-scale circulations.

Seasonal shifts in cloudiness at the BCO appear representative of processes in the broader trades (Medeiros et al. 2010; Medeiros and Stevens 2011) and are proving helpful as a baseline for evaluating the representation of trade wind cloudiness in largescale models (Nuijens et al. 2015). Measurements at the BCO suggest that the parameterization of shallow convection in climate models adequately represents 
TABLE I. Summary of BCO measurement systems. Further information about the operation and technical specifications of the measurement systems are provided in the electronic supplement.

\begin{tabular}{|c|c|}
\hline System & Measurements \\
\hline Raman lidar & $\begin{array}{l}\text { Measures particle backscatter at 355, 532, and I,064 nm. Particle extinction is } \\
\text { derived from pure rotational Raman signals at } 355 \text { and } 532 \mathrm{~nm} \text {. The depolar- } \\
\text { ization ratio is measured at } 532 \mathrm{~nm} \text {. Water vapor mixing ratio derived and air } \\
\text { temperature from Raman signals at } 355 \mathrm{~nm} \text {. In early } 2017 \text { the existing system } \\
\text { will be replaced by the lidar component of the Cloud Observing Radar and Lidar } \\
\text { (CORAL) system designed to measure humidity within } 2 \% \text { at a } 3-\mathrm{m} \text { range and } 5-\mathrm{s} \\
\text { temporal resolution. }\end{array}$ \\
\hline CORAL cloud radar & $\begin{array}{l}\text { A vertically pointing Metek } \mathrm{K}_{\alpha}(35.5 \mathrm{GHz}) \text { polarized Doppler radar measures } \\
\text { clouds and precipitation. It is operated at a high }(-60 \mathrm{dBZ} \text { at } 2 \mathrm{~km} \text { for } 15-\mathrm{m} \text { range } \\
\text { gates and } 2 \text {-s averaging) sensitivity and a narrow }\left(0.3^{\circ}\right) \text { more isolated beam to } \\
\text { avoid clutter. }\end{array}$ \\
\hline KATRIN cloud radar & $\begin{array}{l}\text { A Metek scanning } \mathrm{K}_{\alpha}(35.5 \mathrm{GHz}) \text { polarized Doppler radar measures clouds and } \\
\text { precipitation. It is operated at a high }(-52 \mathrm{dBZ} \text { at } 5 \mathrm{~km}) \text { sensitivity and has a } 0.5^{\circ} \\
\text { beamwidth (at half maximum). }\end{array}$ \\
\hline $\begin{array}{l}\text { Scanning precipitation } \\
\text { radar }\end{array}$ & $\begin{array}{l}\text { A high-performance METEOR } 500 \mathrm{~S} \text { Gematronik radar operating in the } \mathrm{S} \text { band } \\
\text { measures precipitation with a } 300-\mathrm{m} \text { range resolution and a sensitivity of } \\
-12.5 \mathrm{dBZ} \text { at } 50 \mathrm{~km} \text {. It has been operational since } 2008 \text { and is maintained by the } \\
\text { Barbados Meteorological Services. }\end{array}$ \\
\hline Microwave radiometer & $\begin{array}{l}\text { A scanning RPG Radiometer Physics GmbH Humidity and Temperature Profiler } \\
\text { (HATPRO) radiometer maintained by the University of Cologne measures seven } \\
\text { brightness temperatures around the water vapor line at } 22.24 \mathrm{GHz} \text {. }\end{array}$ \\
\hline Micro Rain Radar & $\begin{array}{l}\text { A frequency-modulated continuous-wave radar, the Micro Rain Radar (MRR-2), } \\
\text { operating in the } \mathrm{X} \text { band ( } 24 \mathrm{Ghz} \text { ). Two MRRs are deployed, one at the BCO and } \\
\text { another at the CIMH. }\end{array}$ \\
\hline Ceilometer & $\begin{array}{l}\text { A Jenoptik } 15-\mathrm{K} \text { laser ceilometer with a } 0.4-\mathrm{mrad} \text { field of view measures back- } \\
\text { scattered energy at } 1064 \mathrm{~nm} \text {. }\end{array}$ \\
\hline Radiation & $\begin{array}{l}\text { A Solys2 sun tracker with two CP2I pyranometers (shaded and nonshaded) mea- } \\
\text { suring visible radiation }(0.285-2.80 \mu \mathrm{m}) \text {, a CGR4 shaded pyrgeometer measuring } \\
\text { thermal radiation }(4.50-42.0 \mu \mathrm{m}) \text {, and a CHPI pyrheliometer measuring direct } \\
\text { irradiance }(0.20-4.00 \mu \mathrm{m}) \text {. Operational since March } 2015 \text {. }\end{array}$ \\
\hline Wind lidar & $\begin{array}{l}\text { A Halo Photonics Streamline Pro wind lidar system for profiling the wind in the } \\
\text { lower }(2 \mathrm{~km}) \text { atmosphere. }\end{array}$ \\
\hline Atmospheric composition & $\begin{array}{l}\text { The University of Miami makes daily filter samples from a 17-m tower (atop a } \\
30-\mathrm{m} \text { cliff) at nearby Ragged Point. }\end{array}$ \\
\hline Standard meteorology & $\begin{array}{l}\text { Continuous meteorological measurements are provided by a Vaisala WXT520 } \\
\text { sensor, which measures barometric pressure, humidity, precipitation, tempera- } \\
\text { ture, and wind speed and direction from a mast at a height of } 5 \mathrm{~m} \text {. }\end{array}$ \\
\hline All-sky imager & $\begin{array}{l}\text { A self-made all-sky imager provides high-resolution digital photograms every } \\
\text { minute. }\end{array}$ \\
\hline Webcams & $\begin{array}{l}\text { Four webcams oriented southeast, northeast, northward, and westward take } \\
\text { visible images every minute. }\end{array}$ \\
\hline Water vapor DIAL & $\begin{array}{l}\text { DIAL (Ertel et al. 2005) was operated for } 5 \text { months during the period between } \\
\text { November } 2011 \text { and May } 2012 \text {. The DIAL transmits in the near infrared, at } \\
820 \mathrm{~nm} \text {, where appropriate water vapor absorption lines are located. }\end{array}$ \\
\hline
\end{tabular}

the basic depth and structure of the cloud layer but that cloudiness varies more with wind speed in nature than it does in climate simulations, and cloud amount near cloud base is more constant in the data than in models (Brueck et al. 2015; Nuijens et al. 2015).
The BCO also functions as a laboratory for studying aerosol-cloud interactions. Aerosol optical depth can vary greatly, largely as a result of dust transport from North Africa. Dust episodes can produce daily averaged optical depths larger than 0.4 and are most 
a)

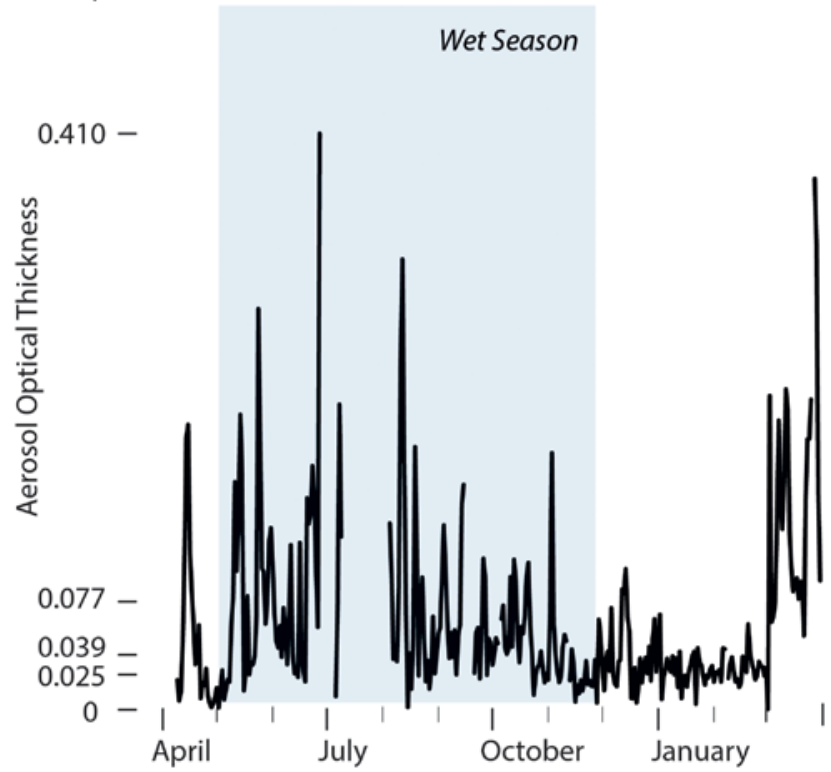

b)

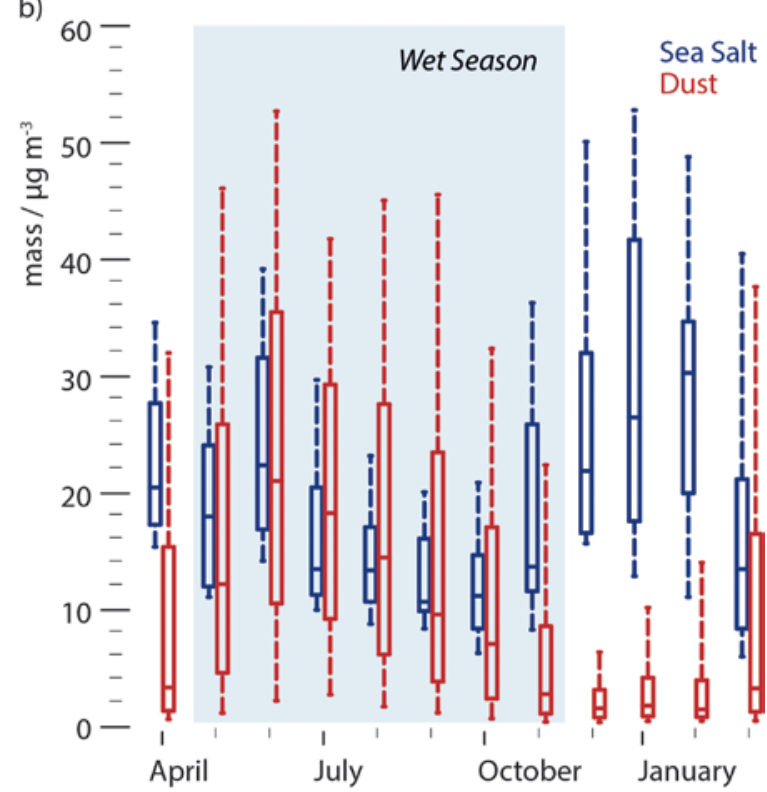

FIG. 8. (a) Time series of Raman lidar optical depth at $335 \mathrm{~nm}$ integrated between 0.5 and $15 \mathrm{~km}$ during the first year of BCO operations. Tick marks on the $y$ axis denote the minimum, maximum, median, and interquartile range of data. (b) Daily median, interquartile, and 10 th- and 90 th-percentile values of dust and sea salt calculated from II years (2000-10) of filter samples at Ragged Point.

common in the May-September time frame (Fig. 8). During the dry season, particularly January and February, the flow from the east-northeast is less aerosol laden, with optical depths remaining well below 0.05 for extended periods of time, and very little dust is evident. The interplay between dust transport and precipitation leads to considerable variance in aerosol optical depth during the wet season, so that despite the larger dust loading, aerosol optical depths may still drop to values less than 0.01 (Fig. 8a) and sea salt is likewise reduced (Fig. $8 \mathrm{~b}$ ). Such very clean periods are thought to occur more often during the wet season when wet scavenging is strong but also because climatologically lighter winds lead to less sea salt aerosol to begin with (Fig. 8b). The slightly higher clear-sky extinction (Fig. 7d) above $5 \mathrm{~km}$ in October is consistent with slightly more dust during this period, although differences between dust amounts in February and October are small (Fig. 8b).

The aerosol varies considerably over the $\mathrm{BCO}$, seemingly much more profoundly than the meteorology; even so, it has been difficult to demonstrate a robust influence of the aerosol on important cloud properties, such as the tendency to form precipitation. An analysis of two years of data from the KATRIN (named for scientist Katrin Lehmann) cloud radar shows a strong influence of slight changes in ambient relative humidity on cloud development but no robust signature of aerosol effects (Lonitz et al. 2015). This finding is consistent with high-resolution modeling, which suggests that even a few percent change in the cloud-layer humidity has as much effect on the echo development of shallow clouds as does a twofold change in cloud droplet number concentrations (Seifert et al. 2016).

\section{ANCHORING INVESTIGATIONS ON THE EDGE OF THE ITCZ. Measurements at the BCO} have helped support a number of recent field studies: the Barbados Aerosol Cloud Experiment (BACEX) in 2010 and two Cloud, Aerosol, Radiation and Turbulence in the Trade Wind Regime over Barbados (CARRIBA) campaigns in November 2010 and April 2011 (Siebert et al. 2013). During CARRIBA particle measurements were made in situ at the neighboring Ragged Point, and profiling of the turbulent structure of the cloudy boundary layer upwind of the BCO was performed with a helicopterborne payload. During the recent Saharan Aerosol Long-Range Transport and Aerosol-Cloud-Interaction Experiment (SALTRACE) 2013 campaign, additional lidars and in situ particle samplers were deployed both on the CIMH campus and at Ragged Point, and air masses were sampled from the German national aeronautics and space research center [Deutsches Zentrum für Luftund Raumfahrt (DLR)] Falcon aircraft, which in addition to an array of particle probes also deployed a wind lidar system. 
ALO is a Gulfstream 550 with a H large payload $(2,800 \mathrm{~kg}, 800 \mathrm{~kg}$ with maximum fuel), long range $(12,500 \mathrm{~km})$ and a high (15.5 km) ceiling. In support of measurements at the $\mathrm{BCO}$ a suite of remote sensing instrumentation has been developed for HALO in cooperation with the DLR, the University of Hamburg, and the University of Cologne. The instrumentation includes three banks of radiometers with 26 channels spanning the $\mathrm{K}$ and $\mathrm{V}$ bands, a $\mathrm{K}_{\alpha}$ cloud radar very similar to the KATRIN system on Barbados but with a somewhat reduced ( $-38 \mathrm{dBZ}$ at $5 \mathrm{~km})$ sensitivity, and a water vapor DIAL lidar [Water Vapour Lidar Experiment in Space (WALES); Wirth et al 2009]. The microwave instrumentation is described in more detail by Mech et al. (20|4). The remote sensing instrumentation looks in the nadir direction from a special belly pod mounted on the forward fuselage of HALO (Fig. SBI). Dropsondes can be launched from the rear of the aircraft, and differential optical absorption spectroscopy provides further information about the state of the air mass below HALO. A high-resolution spectroradiometer (HALO-SR;
Fricke et al. 2014) measured radiances in the spectral range from 0.35 to $2.0 \mu \mathrm{m}$, with a spectral resolution of $0.003 \mu \mathrm{m}$ below $\mathrm{I} \mu \mathrm{m}$ and $0.016 \mu \mathrm{m}$ between I and $2 \mu \mathrm{m}$. The composition of various trace gases was measured using a miniature differential optical absorption spectroscopy (mini-DOAS). The HALO mini-DOAS instrument was developed by the Institut für Umweltphysik at the University of Heidelberg. It consists of a six-channel (ultraviolet/visible/infrared) spectroradiometer that measures trace gas amounts using scattered sunlight in the limb and nadir directions.

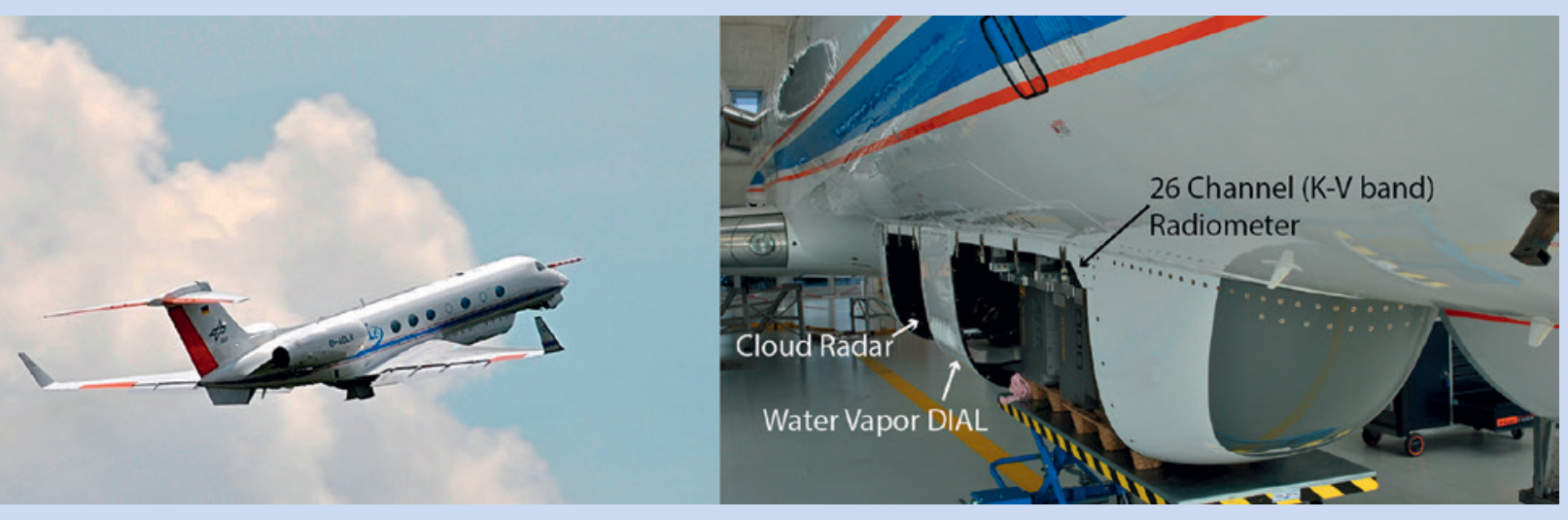

FIG. SBI. (left) HALO with the remote sensing belly pod mounted to its fuselage. (right) Closeup image of belly pod showing three compartments for cloud radar, water vapor lidar, and three-bank, 26-channel radiometer.

The BCO is also anchoring aircraft-baded studies of tropical and trade wind convection with the German High Altitude and Long Range Research Aircraft (HALO; see sidebar on HALO). The first HALO campaign, Next-Generation Aircraft Remote Sensing for Validation Studies (NARVAL)-South, took place between 10 and 20 December 2013 (Klepp et al. 2014; see also the electronic supplement). NARVAL-South comprised eight flights over the tropical North Atlantic (Fig. 9) that were designed to test its payload of nadir-looking remote sensing instruments and investigate the extent to which measurements at the $\mathrm{BCO}$ are representative of the broader trades. Seven of the eight research flights included long coincident legs along the path of the A-Train constellation of satellites. The legs allowed for a comparison of the lidar and radar remote sensing from HALO to be compared with the Cloud-Aerosol Lidar with Orthogonal Polarization (CALIOP) lidar on Cloud-Aerosol Lidar and Infrared Pathfinder Satellite Observations (CALIPSO) and the cloud profiling radar on CloudSat. Sixty-seven dropsondes were also successfully launched from HALO, mostly in a region of the subtropical Atlantic (Fig. 9).

Conditions during NARVAL-South were characterized by a relatively homogeneous large-scale environment and an exceptionally dry free troposphere, very much consistent with the measurements at the BCO. Over a stretch of thousands of kilometers convection was confined to a shallow (topping at $1.5-3 \mathrm{~km}$ ) marine layer, above which the atmosphere was very dry and cloud free. The homogeneity in the large-scale conditions allowed a clear trade wind structure, with a pronounced trade wind temperature inversion and hydrolapse, to emerge from the mean sounding taken from 46 sondes launched south of $20^{\circ} \mathrm{N}$ and west of $25^{\circ} \mathrm{W}$ (Fig. 10). The main features of this mean sounding are also evident in individual 


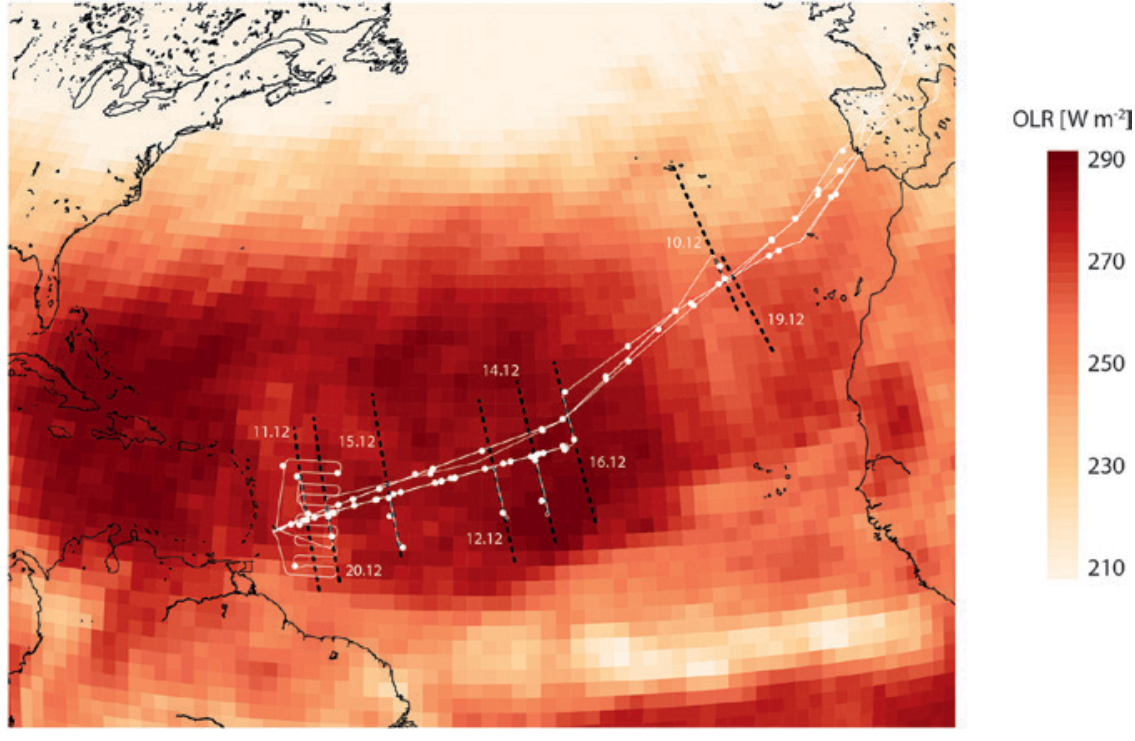

FIG. 9. Overview of HALO trade wind flights. Shown are the flight paths during the NARVAL-South campaign overlaid on outgoing longwave radiation (OLR) measurements from the Atmospheric Infrared Sounder (AIRS) for the same period. Eight flights were performed, four of which crossed the entire Atlantic. Seven flights included A-Train under flight legs (evident as north-northeast-south-southwest jigs) for intercomparisons with CloudSat and CALIPSO.

soundings. Here, the top of a relatively thick inversion layer is defined by the maximum in the saturated moist static energy and the minimum in moist static energy at about $3 \mathrm{~km}$. This inversion demarcates the depth of the deepest convective clouds. For the most part, moist convection is confined between the top of the subcloud layer at about $600 \mathrm{~m}$ and the base of the trade wind inversion at about $1.75 \mathrm{~km}$, and the free-tropospheric humidity is at most a few percent (Fig. 10), similar to what is observed in the winter trades at the BCO.

During the period of the NARVAL flights, the BCO was influenced by deeper convection, which was prevalent south of the area of flight operations near the Guyana coast. This is evident in lower values of outgoing longwave radiation in Fig. 9, which extended northward toward Barbados on some of the days, for example, 14 December. The radar imagery from the BCO cloud radar KATRIN shows the contrast between periods of deeper convection and the more suppressed conditions more typical of the trades (Fig. 11) and what was sampled by HALO. Deeper convection over and south of Barbados maintained elevated cirrus outflow layers on 14 December, transitioning to more suppressed conditions with diminishing high clouds and convection capped at about $2-3 \mathrm{~km}$ thereafter. The three modes of convection seen in this 3 -day period are similar to what is seen in the average over 4 years (Fig. 7).
Radar imagery emphasizes that very shallow moist convective systems are not infrequent and can precipitate heavily. This is the case for an event measured around 1330 UTC 15 December (Fig. 11, see inset), for which a convective cluster with tops only at $2.5 \mathrm{~km}$ sustains an echo that is greater than $40 \mathrm{dBZ}$. These types of systems are commonplace in the $\mathrm{BCO}$ record, as evidenced by the daily quick-look imagery. Similar systems featured prominently in the distribution of cloudiness over the broader Atlantic trades during the HALO overpasses (see supplemental information) and were also often observed during the Rain in Cumulus over the Ocean (RICO) field study (Nuijens et al. 2009). This suggests that the convective systems sampled by the $\mathrm{BCO}$ are not just a local feature but play an important role in the mass and moisture budgets in the trades, as demonstrated with the help of BCO data by Burdanowitz et al. (2015).

In demonstrating the capability of the HALO aircraft to characterize the large-scale environment through active remote sensing and from dropsondes,

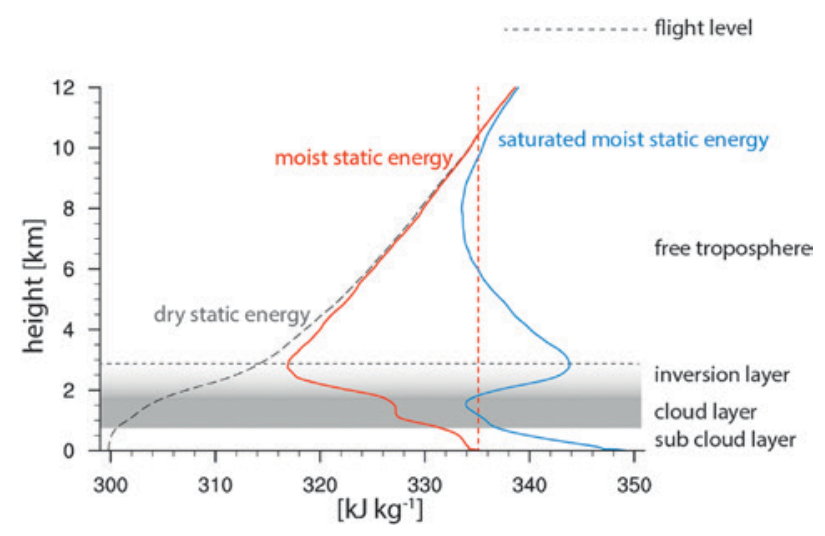

FIG. I0. Trade wind sounding from 46 dropsondes launched during a 10-day period over the north-central subtropical Atlantic: dry static energy s (black dashed line), moist static energy $h$ (red), and saturation moist-static energy $h_{s}$ (blue). The relative position of $h$ between $s$ and $h_{s}$ measures the relative humidity. 


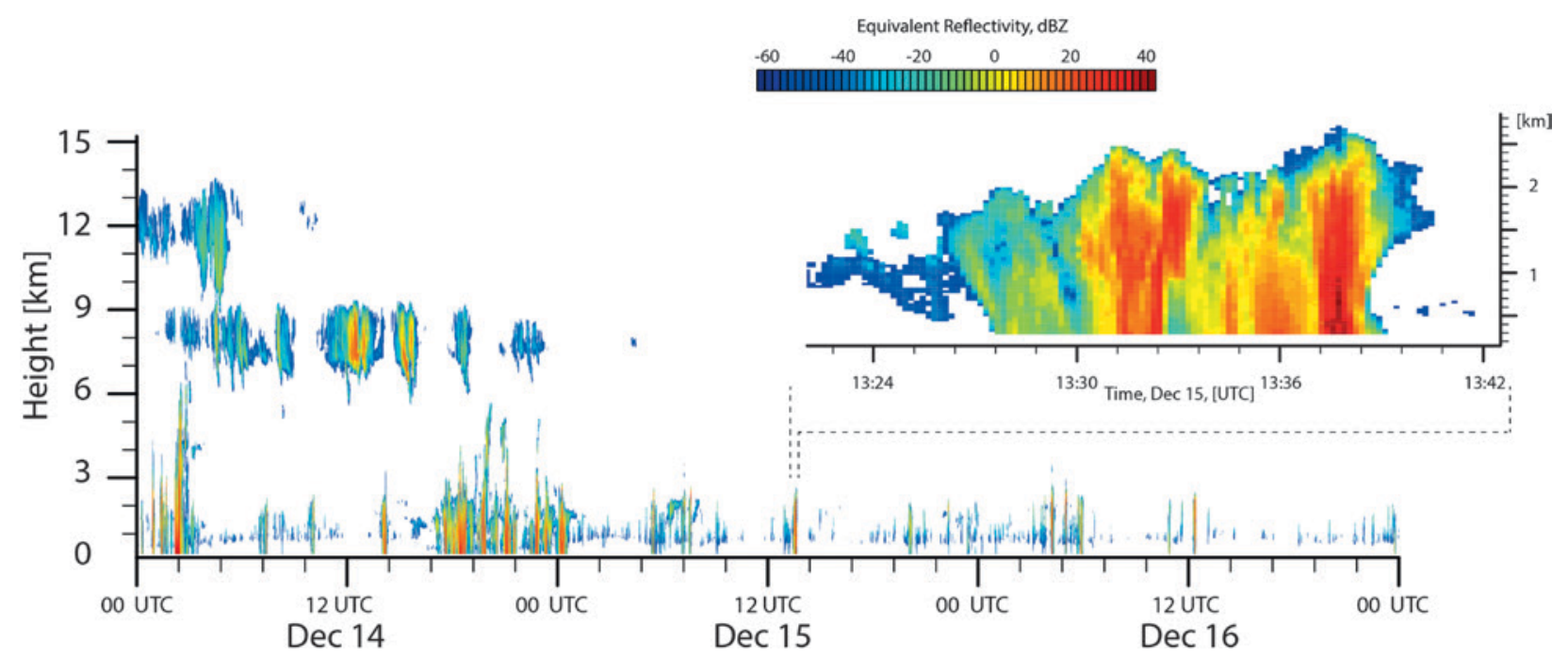

FIG. II. Radar reflectivity profiles from the KATRIN cloud radar at the BCO for the 3-day period I4-I6 Dec 2013. Inset shows the details of a convective system passing over the site near I330 UTC I5 Dec 2013 with a maximum echo greater than $40 \mathrm{dBZ}$ near the surface at 1338 UTC arising from a system whose echo tops were at an altitude of less than $3 \mathrm{~km}$.

NARVAL has set the stage for subsequent field studies. NARVAL-II will take place in August of 2016 and will use Barbados as its base of operations to explore the capability of measurements of the divergence of the horizontal wind (from dropsondes) and thermodynamic profiles (also from remote sensing) to constrain the mass, heat, and moisture budgets in an area of some $10^{4} \mathrm{~km}^{2}$, typical of the grid cell in a general circulation model. These types of measurements are being performed to help understand the interaction of shallow convection with its large-scale environment, including the role of shallow trade wind layers in organizing nearby deep convection. NARVAL-II will help inform the design of, and contribute to, a larger, multiplatform field study, being proposed for 2019. This campaign [Elucidating the Role of CloudCirculation Coupling in Climate $\left(\right.$ EUREC $\left.\left.^{4} \mathrm{~A}\right)\right]$ is a French initiative to leverage ongoing measurements by HALO, and at the BCO, to explore new ideas for testing understanding of how clouds and convection interact with the large-scale environment. Data from initiatives such as these, combined with the context provided by long-term measurements at the BCO, are bringing a fresh wind to efforts to understand the relationship between cloudiness, circulation, and climate change.

ACKNOWLEDGMENTS. The Barbados Museum and Historical Society, which owns the land on which the BCO is situated, is thanked for making the site available for these measurements. We thank the Max Planck Society for the Advancement of Science for its unflagging support of basic science as it has made these measurements possible. Tropical Rainfall Measuring Mission (TRMM) data provided by the TRMM science team through an international project jointly sponsored by the Japan National Space Development Agency (NASDA) and the U.S. National Aeronautics and Space Administration (NASA) Office of Earth Sciences. The OLR data are taken from the AIRS instrument. DLR and the German research community are thanked for their support of HALO. HYSPLIT was used to calculate back trajectories. Steffan Bos is thanked for his analysis of the CloudSat overpasses during NARVAL and his drafting of Fig. ES1. Thorsten Mauritsen is thanked for his help with the experimental design and sensitivity study that produced Fig. 1. Saskia Brose helped process the composition data from Ragged Point, and Monika Pfeiffer contributed to the development of the electronics within the lidar system. The University of Miami site at Ragged Point is largely supported by the U.S. NSF and NASA. J. M. Prospero gratefully acknowledges the Manning Estate, Barbados, for use of its land at Ragged Point and thanks Edmund Blades and Peter Sealy of Barbados for maintaining and operating the facility. Primary data and scripts used in the analysis and other supplementary information that may be useful in reproducing the authors' work are archived by the Max Planck Institute for Meteorology and can be obtained by contacting publications@mpimet.mpg.de.

\section{REFERENCES}

Ackerman, T. P., and G. M. Stokes, 2003: The atmospheric radiation measurement program. Phys. Today, 56, 38-44, doi:10.1063/1.1554135. 
Amante, C., and B. W. Eakins, 2009: ETOPO1 1 arcminute global relief model: Procedures, data sources and analysis. NOAA Tech. Memo. NESDIS NGDC24, 19 pp.

Augstein, E., H. Schmidt, and F. Ostapoff, 1974: The vertical structure of the atmospheric planetary boundary layer in undisturbed trade winds over the Atlantic Ocean. Bound.-Layer Meteor., 6, 129-150, doi:10.1007/BF00232480.

Betts, A. K., 1974: Thermodynamic classification of tropical convective soundings. Mon. Wea. Rev., 102, 760-764, doi:10.1175/1520-0493(1974)102<0760:TCO TCS $>2.0 . C O ; 2$.

Bony, S., and J. L. Dufresne, 2005: Marine boundary layer clouds at the heart of tropical cloud feedback uncertainties in climate models. Geophys. Res. Lett., 32, L20806, doi:10.1029/2005GL023851.

— mate sensitivity. Nat. Geosci., 8, 261-268, doi:10.1038 /ngeo2398.

Boucher, O., and Coauthors, 2013: Clouds and aerosols. Climate Change 2013: The Physical Science Basis, T. F. Stocker et al., Eds., Cambridge University Press, 571-657.

Bretherton, C. S., and Coauthors, 2004: The EPIC 2001 stratocumulus study. Bull. Amer. Meteor. Soc., 85, 967-977, doi:10.1175/BAMS-85-7-967.

—, P. N. Blossey, and M. Khairoutdinov, 2005: An energy-balance analysis of deep convective selfaggregation above uniform SST. J. Atmos. Sci., 62, 4273-4292, doi:10.1175/JAS3614.1.

Brient, F., T. Schneider, Z. Tan, and S. Bony, 2016: Shallowness of tropical low clouds as a predictor of climate models' response to warming. Climate Dyn., doi:10.1007/s00382-015-2846-0, in press..

Brueck, M., L. Nuijens, and B. Stevens, 2015: On the seasonal and synoptic time-scale variability of the North Atlantic trade wind region and its low-level clouds. J. Atmos. Sci., 72, 1428-1446, doi:10.1175 /JAS-D-14-0054.1.

Burdanowitz, J., L. Nuijens, B. Stevens, and C. Klepp, 2015: Evaluating light rain from satellite- and ground-based remote sensing data over the subtropical North Atlantic. J. Appl. Meteor. Climatol., 54, 556-572, doi:10.1175/JAMC-D-14-0146.1.

Chen, S., and Coauthors, 2015: A study of CINDY/ DYNAMO MJO suppressed phase. J. Atmos. Sci., 72, 3755-3779, doi:10.1175/JAS-D-13-0348.1.

Chepfer, H., S. Bony, D. Winker, G. Cesana, J. L. Dufresne, P. Minnis, C. J. Stubenrauch, and S. Zeng, 2010: The GCM-Oriented CALIPSO Cloud Product (CALIPSO-GOCCP). J. Geophys. Res., 115, D00H16, doi:10.1029/2009JD012251.
Clothiaux, E. E., T. P. Ackerman, G. G. Mace, K. P. Moran, R. T. Marchand, M. A. Miller, and B. E. Martner, 2000: Objective determination of cloud heights and radar reflectivities using a combination of active remote sensors at the ARM CART sites. J. Appl. Meteor., 39, 645-665, doi:10.1175/1520 -0450(2000)039<0645:ODOCHA>2.0.CO;2.

Doherty, O. M., N. Riemer, and S. Hameed, 2008: Saharan mineral dust transport into the Caribbean: Observed atmospheric controls and trends. J. Geophys. Res., 113, D07211 doi:10.1029/2007JD009171.

Emanuel, K., A. A. Wing, and E. M. Vincent, 2014: Radiative-convective instability. J. Adv. Model. Earth Syst., 6, 75-90, doi:10.1002/2013MS000270.

Ertel, K., H. Linné, and J. Bösenberg, 2005: Injectionseeded pulsed Ti:sapphire laser with novel stabilization scheme and capability of dual-wavelength operation. Appl. Opt., 44, 5120-5126, doi:10.1364 /AO.44.005120.

Fricke, C., A. Ehrlich, E. Jäkel, B. Bohn, M. Wirth, and M. Wendisch, 2014: Influence of local surface albedo variability and ice crystal shape on passive remote sensing of thin cirrus. Atmos. Chem. Phys., 14, 1943-1958, doi:10.5194/acp-14-1943-2014.

Gerber, H., G. Frick, S. P. Malinowski, H. Jonsson, D. Khelif, and S. K. Krueger, 2013: Entrainment rates and microphysics in POST stratocumulus. $J$. Geophys. Res. Atmos., 118, 12 094-12 109, doi:10.1002 /jgrd.50878.

Holland, J. Z., 1970: Preliminary report on the BOMEX sea-air interaction program. Bull. Amer. Meteor. Soc., 51, 809-821, doi:10.1175/1520 -0477(1970)051<0809:PROTBS>2.0.CO;2.

— the atmospheric mass, energy, and momentum budgets over a 500-kilometer square of tropical ocean. Mon. Wea. Rev., 101, 44-55, doi:10.1175/1520 -0493(1973)101<0044:MOTAME>2.3.CO;2.

Illingworth, A. J., and Coauthors, 2007: Cloudnet: Continuous evaluation of cloud profiles in seven operational models using ground-based observations. Bull. Amer. Meteor. Soc., 88, 883-898, doi:10.1175 /BAMS-88-6-883.

Johnson, R. H., M. Rickenbach, S. A. Rutledge, P. E. Ciesielski, and W. H. Schubert, 1999: Trimodal characteristics of tropical convection. J. Climate, 12, 2397-2418, doi:10.1175/1520-0442(1999)012<2397:TC OTC>2.0.CO;2.

Klepp, C., F. Ament, S. Bakan, L. Hirsch, and B. Stevens, 2014: NARVAL campaign report. Max Planck Institute for Meteorology Tech. Rep. 164, 218 pp. [Available online at www.mpimet.mpg.de/fileadmin /publikationen/Reports/WEB_BzE_164_last.pdf.] 
Knight, C. A., and L. J. Miller, 1998: Early radar echoes from small, warm cumulus: Bragg and hydrometeor scattering. J. Atmos. Sci., 55, 2974-2992, doi:10.1175/1520-0469(1998)055<2974:EREFSW>2 $0 . \mathrm{CO} ; 2$.

Loeb, N. G., B. A. Wielicki, D. R. Doelling, G. L. Smith, D. F. Keyes, S. Kato, N. Manalo-Smith, and T. Wong, 2009: Toward optimal closure of the Earth's top-ofatmosphere radiation budget. J. Climate, 22, 748-766, doi:10.1175/2008JCLI2637.1.

Löhnert, U., S. Crewell, and C. Simmer, 2004: An integrated approach toward retrieving physically consistent profiles of temperature, humidity, and cloud liquid water. J. Appl. Meteor., 43, 1295-1307, doi:10.1175/1520 -0450(2004)043<1295:AIATRP>2.0.CO;2.

Long, C. N., and Coauthors, 2013: ARM research in the equatorial western Pacific: A decade and counting. Bull. Amer. Meteor. Soc., 94, 695-708, doi:10.1175 /BAMS-D-11-00137.1.

Lonitz, K., B. Stevens, L. Nuijens, L. Hirsch, V. Sankt, and A. Seifert, 2015: The signature of aerosols and meteorology in long-term cloud radar observations of trade wind cumuli. J. Atmos. Sci., 72, 4643-4659, doi:10.1175/JAS-D-14-0348.1.

Mech, M., E. Orlandi, S. Crewell, F. Ament, L. Hirsch, M. Hagen, G. Peters, and B. Stevens, 2014: HAMP_The microwave package on the High Altitude and Long Range Research Aircraft (HALO). Atmos. Meas. Tech., 7, 4539-4553, doi:10.5194/amt-7-4539-2014.

Medeiros, B., and B. Stevens, 2011: Revealing differences in GCM representations of low clouds. Climate Dyn., 36, 385-399, doi:10.1007/s00382-009-0694-5.

—, L. Nuijens, C. Antoniazzi, and B. Stevens, 2010: Lowlatitude boundary layer clouds as seen by CALIPSO. J. Geophys. Res., 115, D23207, doi:10.1029/2010JD014437.

Moran, K. P., B. E. Martner, M. J. Post, R. A. Kropfli, D. C. Welsh, and K. B. Widener, 1998: An unattended cloud-profiling radar for use in climate research. Bull. Amer. Meteor. Soc., 79, 443-455, doi:10.1175/1520 -0477(1998)079<0443:AUCPRF>2.0.CO;2.

Muller, C. J., and S. Bony, 2015: What favors convective aggregation and why? Geophys. Res. Lett., 42, 5626-5634, doi:10.1002/2015GL064260.

Neggers, R. A. J., J. D. Neelin, and B. Stevens, 2007: Impact mechanisms of shallow cumulus convection on tropical climate dynamics. J. Climate, 20, 2623-2642, doi:10.1175/JCLI4079.1.

Nuijens, L., B. Stevens, and A. P. Siebesma, 2009: The environment of precipitating shallow $\mathrm{cu}$ mulus convection. J. Atmos. Sci., 66, 1962-1979, doi:10.1175/2008JAS2841.1.

- I. Serikov, L. Hirsch, K. Lonitz, and B. Stevens, 2014: The distribution and variability of low-level cloud in the North Atlantic trades. Quart. J. Roy. Meteor. Soc., 140, 2364-2374, doi:10.1002/qj.2307.

_, B. Medeiros, I. Sandu, and M. Ahlgrimm, 2015: The behavior of trade-wind cloudiness in observations and models: The major cloud components and their variability. J. Adv. Model. Earth Syst., 7, 600-616, doi:10.1002/2014MS000390.

Prinn, R. G., and Coauthors, 2000: A history of chemically and radiatively important gases in air deduced from ALE/GAGE/AGAGE. J. Geophys. Res., 105, 17 751-17 792, doi:10.1029/2000JD900141.

Prospero, J. M., 1968: Atmospheric dust studies on Barbados. Bull. Amer. Meteor. Soc., 49, 645-652.

_ , and T. N. Carlson, 1972: Vertical and areal distribution of Saharan dust over the western equatorial North Atlantic Ocean. J. Geophys. Res., 77, 5255-5265, doi:10.1029/JC077i027p05255.

—, and P. J. Lamb, 2003: African droughts and dust transport to the Caribbean: Climate change implications. Science, 302, 1024-1027, doi:10.1126 /science.1089915.

Rauber, R. M., B. Stevens, H. T. Ochs III, and C. Knight, 2007: Rain in Cumulus over the Ocean: The RICO campaign. Bull. Amer. Meteor. Soc., 88, 1912-1928, doi:10.1175/BAMS-88-12-1912.

Raymond, D. J., G. B. Raga, C. S. Bretherton, J. Molinari, C. López-Carrillo, and Ž. Fuchs, 2003: Convective forcing in the intertropical convergence zone of the eastern Pacific. J. Atmos. Sci., 60, 2064-2082, doi:10.1175/1520 -0469(2003)060<2064:CFITIC>2.0.CO;2.

Rémillard, J., P. Kollias, E. Luke, and R. Wood, 2012: Marine boundary layer cloud observations in the Azores. J. Climate, 25, 7381-7398, doi:10.1175/JCLI -D-11-00610.1.

Russell, L. M., and Coauthors, 2013: Eastern Pacific emitted aerosol cloud experiment. Bull. Amer. Meteor. Soc., 94, 709-729, doi:10.1175/BAMS-D-12-00015.1.

Seifert, A., T. Heus, R. Pincus, and B. Stevens, 2015: Large-eddy simulation of the transient and nearequilibrium behavior of precipitating shallow convection. J. Adv. Model. Earth Syst., 7, 1918-1937, doi:10.1002/2015MS000489.

Sherwood, S. C., S. Bony, and J.-L. Dufresne, 2014: Spread in model climate sensitivity traced to atmospheric convective mixing. Nature, 505, 37-42, doi:10.1038/nature12829.

Siebert, H., and Coauthors, 2013: The fine-scale structure of the trade wind cumuli over Barbados: An introduction to the CARRIBA project. Atmos. Chem. Phys., 13, $10061-10077$, doi:10.5194/acp-13 -10061-2013.

Siebesma, A. P., and Coauthors, 2003: A large eddy simulation intercomparison study of shallow 
cumulus convection. J. Atmos. Sci., 60, 1201-1219, doi:10.1175/1520-0469(2003)60<1201:ALESIS $>2.0$. $\mathrm{CO} ; 2$.

Smith, R. B., P. Schafer, D. J. Kirshbaum, and E. Regina, 2009: Orographic precipitation in the tropics: Experiments in Dominica. J. Atmos. Sci., 66, 1698-1716, doi:10.1175/2008JAS2920.1.

Stephens, G. L., and Coauthors, 2008: CloudSat mission: Performance and early science after the first year of operation. J. Geophys. Res., 113, D00A18, doi:10.1029/2008JD009982.

Stevens, B., and Coauthors, 2001: Simulations of trade wind cumuli under a strong inversion. J. Atmos. Sci., 58, 1870-1891, doi:10.1175/1520 -0469(2001)058<1870:SOTWCU>2.0.CO;2.

—, and Coauthors, 2003: Dynamics and Chemistry of Marine Stratocumulus-DYCOMS-II. Bull. Amer. Meteor. Soc., 84, 579-593, doi:10.1175/BAMS-84-5579.

—- and Coauthors, 2013: Atmospheric component of the MPI-M Earth system model: ECHAM6. J. Adv. Model. Earth Syst., 5, 146-172, doi:10.1002/jame.20015.

Tiedtke, M., 1989: A comprehensive mass flux scheme for cumulus parameterization in large-scale models.
Mon. Wea. Rev., 117, 1779-1800, doi:10.1175/1520 -0493(1989)117<1779:ACMFSF>2.0.CO;2.

Twohy, C. H., and Coauthors, 2009: Saharan dust particles nucleate droplets in eastern Atlantic clouds. Geophys. Res. Lett., 36, L01807, doi:10.1029/2008GL035846.

Winker, D. M., and Coauthors, 2010: The CALIPSO mission: A global 3D view of aerosols and clouds. Bull. Amer. Meteor. Soc., 91, 1211-1229, doi:10.1175/2010BAMS3009.1.

Wirth, M., A. Fix, P. Mahnke, H. Schwarzer, F. Schrandt, and G. Ehret, 2009: The airborne multi-wavelength water vapor differential absorption lidar WALES: System design and performance. Appl. Phys., 96B, 201-213, doi:10.1007/s00340-009-3365-7.

Wood, R., and Coauthors, 2011: The VAMOS OceanCloud-Atmosphere-Land Study Regional Experiment (VOCALS-REx): Goals, platforms, and field operations. Atmos. Chem. Phys., 11, 627-654, doi:10.5194/acp-11-627-2011.

- and Coauthors, 2015: Clouds, aerosols, and precipitation in the marine boundary layer: An ARM mobile facility deployment. Bull. Amer. Meteor. Soc., 96, 419-440, doi:10.1175/BAMS-D-13-00180.1.

\section{CLIMATE CHANGE/POLICY}

“ This book is timely because global climate change policy is a mess.... Drawing on concrete examples and a broad range of social science theory, this book convincingly makes the case for a social learning approach to both adaptation and emissions mitigation."

- Steve Rayner, James Martin Professor of Science and Civilization, University of Oxford

\section{Adaptive Governance and Climate Change}

RONALD D. BRUNNER AND AMANDA H. LYNCH

As greenhouse gas emissions and temperatures at the poles continue to rise, so do damages from extreme weather events affecting countless lives. Meanwhile, ambitious international efforts to cut emissions have proved to be politically ineffective or infeasible. There is hope, however, in adaptive governance-an approach that has succeeded in some communities and can be undertaken by others around the globe.

In this book:

- A political and historical analysis of climate change policy

- How adaptive governance works on the ground

- Why local, bottom-up approaches should complement global-scale negotiations
Ronald D. Brunner and Amanda H. Lynch Adaptive Governance and Climate Change

(C) 2010, PAPERBACK, 424 PAGES ISBN: 978-1-878220-97-4 AMS CODE: AGCC LIST \$35 MEMBER \$22 
AMS titles now

available as eBooks

at springer.com

\section{AMS BOOKS}

\section{RESEARCH APPLICATIONS HISTORY}

www.ametsoc.org/amsbookstore

Springer

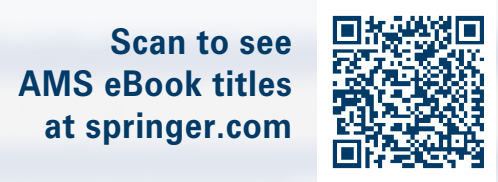

Springer

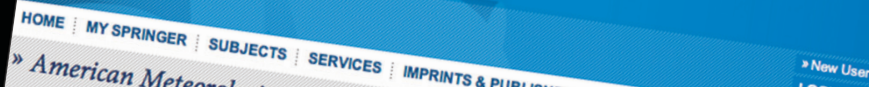

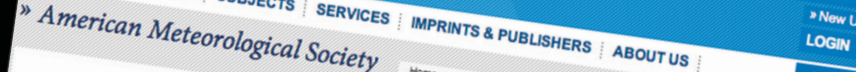

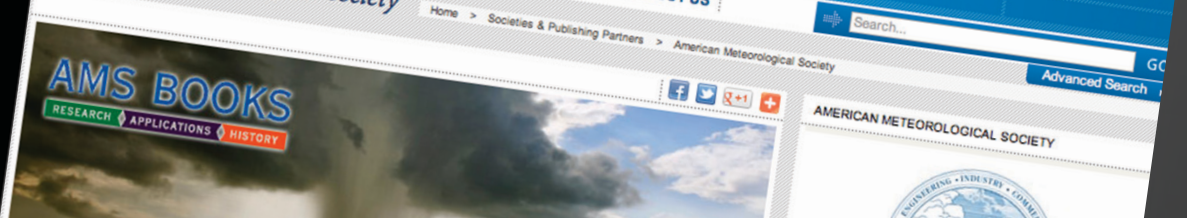

$x^{2}+5=0$

American Meteorological Society

Promoting the development

the atmospheric and rethent and dise

Whatic and related sciences.

American Meteorological Society eBot .

AMs

published by the AMS a monograph publishing pred now

shing program related o ho poer-

Dses a serios

related to th as eBooks) as weil ar ariy out-of-print vol metoorological and historica journals

to the atmospheric sciences a growing list of acades of which have been uroughonographs

ing

Sort listing by:

AMERICAN W O Rolavance

क्षि Export to $\mathrm{cs}$

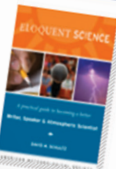

Eloquent Science

A Practical Guit

2009

Price from $\$ 45.00$

Avalabbio forntas

A MER ICA N METEOROLOG ICAL SOCIETY 